\title{
SYNTHESIS, CHARACTERISATION AND ANTIDIABETIC SCREENING OF Co(II),Cu(II),Zn(II) AND La(II) COMPLEXES OF GLIMEPERIDEA STANDARD SYNTHETIC ALLOPATHIC DRUG.
}

Mohammad Tawkir

Saifia college of science, Bhopal, Madhya Pradesh, India Corresponding author Email : msheikh196@gmail.com

\section{Abstract:}

Metal complxes of Glimeperide drugs were prepared and characterized based on elemental analysis, FT-IR, Molar conductance and thermal analysis (TGA and DTG) technique. From elemental analysis data, the complexes were proposed to have general formulae (GLM)2Co2H2O, (GLM)2Cu, (GLM)2Zn, and (GLM)2La2H2O. The molar conductance data reveal that all the metal complexes are non-electrolytic, IR spectra shows that GLM are coordinated to metal ions in a neutral bidentate manner from the ESR spectra and XRDspectra. It is found that the geometrical structures of these complexes are tetrahedral $\mathrm{Cu}$ (II) ,Zn(II) and octrahedral Co(II), La(II). The thermal behavior of these complexes studied using thermogravimetric analysis (TGA and DTG) techniques. The results obtained shows that the hydrated complexes lose water molecules of hydration followed immediately by decomposition of the anions and ligand molecules in the successive unseparate steps. Thermogravimetric analysis was carried out to study the decomposition and various kinetic parameters. Freeman Carroll and Sharp Wentworth method have been applied for calculation of kinetic parameters. While data from freeman Carroll method have been used to determine various thermodynamic parameters such as order of reactions, energy of activation, frequency factor, entropy change, free energy change and apparent entropy change and order of reaction..

\section{Keywords:}

FTIR Spectra, TGA, DTG, , Glimeperide,HPMC-5CPS

\section{Introduction:}

Glimeperide, is a bi-substituted urea derivatives can exist in keto and enolic form when dissolved in an organic solvent and react with various metal ions to form intensely coloured metal complexes that provide the basis for their use as a sensitive reagent. The thermal degradation study of complexes has become a subject of recent interest. It is important property of complexes, which decides the thermal stability and processability of the complexes. The study of thermal 
behaviour of complexes in air at different temperature provides important information about its practical applicability. Iqbal S.A. et.a11., (2005) synthesized the metal complexes of glimeperide characterized by FTIR, elemental analysis and TGA-DTG parameters. The thermal analysis (TGA) was performed at the heating rate of $10^{\circ} \mathrm{C} / \mathrm{min}$. in nitrogen atmosphere. Wilma Cyril et.al2., (2011) studied kinetics and Thermal decomposition of $\mathrm{Cu}(\mathrm{II})$ complex of of hydroxyl quinoline-5-sulphonic acid Thermal data have been analyzed by Freeman Carroll and Sharp-Wentworth method. Thermal analysis (TGA and DTG) is a typical analytical technique to describe the relationship between physico-chemical changes and temperature.1-2 In order to synthesize complexes having practical applications. There is a need to investigate the effect of heat on complexes in order to establish thermal stability. Iqbal and coworkers3-4 have synthesized and characterized complexes of tolbutamide and glimeperide by FTIR, elemental analysis and TGA-DTA technique. Thermal studies of complexes were carried out to determine their mode of decomposition, the activation energy $(\mathrm{Ea})$, order of reaction $(\mathrm{n})$, frequency factor $(Z)$, entropy change (S), Free energy $(\Delta F)$ and apparent entropy change $\left({ }^{*} \mathrm{~S}\right)$. Thermal decomposition curves were discussed with careful attention of minute details. The freeman Carroll and Sharp-Wentworth methods have been used to calculate thermal activation energy and thermal stability. However, very little work has been carried out on the synthesis and characterization and thermal degradation studies of the metal complexes of glimeperide. Hence in this work we prepare complexes of $\mathrm{Cu}$ (II), $\mathrm{Co}(\mathrm{II}), \mathrm{Zn}$ (II) and $\mathrm{La}$ (II) transition and inner transition metals with glimeperide drug molecule. The solid complexes were characterized using different physico-chemical methods, like elemental analysis (C, H, N, S and metal content), IR and thermal analysis (TGA and DTG) 


\section{Material and Method:}

All chemicals used were of analytical reagent grade (A.R.) and of highest purity. They included glimeperide (Zim laboratories, Nagpur), Copper(II) Chloride ,Zinc(II) chloride,Cobalt(II) chloride and Lanthanum(II) Chloride heptahydrate (Hi media Lab, Mumbai) organic solvents used absolute ethyl alcohol, DMF. These solvents were spectroscopic pure from $\mathrm{BDH}$, hydrogen peroxide, hydrochloric and nitric acid (E.Merck) were used. De-ionized water was used in all preparations. 2.2 INSTRUMENTS Molar conductance of solid complexes in DMF was measured using Systronics conductivity meter, elemental microanalyses of the isolated solid complexes for $\mathrm{C}, \mathrm{H}, \mathrm{N}$ were performed at CDRI, Lucknow, using (HMS-932CLECO) Vario elemental analyzers. Infrared spectra were recorded on Perkin-Elmer, FTIR type 1650 spectrophotometer in wave number $400-4000 \mathrm{~cm}-1$. The spectra were recorded as $\mathrm{KBr}$ pellets. The thermogravimetric (TG and DTG) analysis was carried out in dynamic nitrogen atmosphere $(20 \mathrm{ml} . \mathrm{min}-1)$ with a heating rate of $10^{\circ} \mathrm{C} / \mathrm{min}$. using shimatzu

TGA-50H Thermal Analyzer at IIT Bombay (Mumbai) Electronic spectra recorded at Qualichem Laboratory, Nagpur. 2.3 SYNTHESIS OF METAL COMPLEXES Metal complexes are synthesized by adding metal salt solution in appropriate solvent to the solution of the ligand. The mixture was refluxed for 3-4 hours. Then the precipitate of metal complexes was obtained. It was filtered, washed and dried in vacuum desiccators. All selected metals forms 1:2 complexes with glimeperide, were confirmed by Jobs method of continuous variation5 as modified by Turner and Anderson6. 2.4 ESTIMATION OF METALS IN COMPLEXES An accurately weighed portion of the different complexes ranged from 10 to $30 \mathrm{mg}$ was placed in Kjeldhal flask. A measured volume of concentrated nitric acid ranged from 5 to $10 \mathrm{ml}$ was added initially to the powdered complexes to start the fast wet oxidation digestion. This mixture had been digested with some drops of $\mathrm{H} 2 \mathrm{O} 2$ solution using a gradual heating. This treatment was conducted until most of the powdered complexes were dissolved and the remaining solution had the colour of the corresponding metal 
salt. This solution was then diluted upto a $50 \mathrm{ml}$. with distilled water and the metal content was determined by titration against standard EDTA solution at a suitable $\mathrm{pH}$ value using the suitable indicator.

\section{Result and Discussion:}

3.1 COMPOSITION AND STRUCTURES OF METAL COMPLEXES. The isolated solid complexes of $\mathrm{Cu}$ (II), $\mathrm{Co}(\mathrm{II}), \mathrm{Zn}$ (II) and $\mathrm{La}$ (II) with GLM ligands were subjected to elemental analysis (C, H, N, S. and metal content), I.R., Molar conductance, thermal analysis (TG and DTG) to support the tentative structure. The results of elemental analysis listed in table (1) suggest the formulae [Co(GLM)2]2H2O, [Cu(GLM)2], [ $\mathrm{Zn}(\mathrm{GLM}) 2]$, and [La(GLM)2]2H2O for respective complexes. 3.2 MOLAR CONDUCTANCE The complexes were dissolved in DMF and the molar conductivities of 10-3M of their solutions at $298 \mathrm{~K}$ are measured. It is concluded from results listed in table (1) that the complexes are found to have molar conductance values of 13.18 to $30.15 \Omega-1$ mole-1 am-2 indicating that all the metal complexes are non-electrolytes. 3.4 ELECTRONIC SPECTRAL STUDIES Electronic spectra of the ligand shows two high intensity bands at 47431 and $32233 \mathrm{~cm}-1$, indicating $\mathrm{n} \rightarrow \mathrm{n}^{*}$ and $\Pi \rightarrow \Pi$ transitions respectively of the ligand moity.The electronic spectra of $\mathrm{La}(\mathrm{II})$ complex displays band at 32130 and $27393 \mathrm{~cm}-1$ The two bands corresponds to $4 \mathrm{~T} 1 \mathrm{~g}(\mathrm{~F}) \rightarrow 4 \mathrm{~A} 2 \mathrm{~g}(\mathrm{~F}), 4 \mathrm{~T} 1 \mathrm{~g}(\mathrm{~F}) \rightarrow 4 \mathrm{~A} 1 \mathrm{~g}(\mathrm{P})$ suggesting octahedral geometry of these complexes. The $\mathrm{Cu}$ (II) complex displays a band at $26130 \mathrm{~cm}-1$

$4 \mathrm{E} 1 \mathrm{~g}(\mathrm{~F}) \rightarrow 4 \mathrm{~T} 2 \mathrm{~g}(\mathrm{~F}), \mathrm{Zn}(\mathrm{II})$ complex displays single absorption band at $31225 \mathrm{~cm}$ 1.This is due to Ligand $\rightarrow$ Metal charge transfer spectra.. 3.3 IR SPECTRAL STUDIES The IR data of the spectra of GLM ligand and there complexes are listed in table (4). The IR spectra of the complexes are compared with those of the free GLM ligands in order to determine the coordination sites that may be involved in complexation7-15 The tautomeric equilibrium depends on the extent of conjugation, nature and position of the substituent, polarity of the solvent etc 3.5 MAGNETIC SUSCEPTIBILITY STUDIES The room temperature 
magnetic moment of the complexes was found to be 4.66 B.M. which corresponds to the presence of $\mathrm{Co}(\mathrm{II})$, La(II) in octahedral geometry. Zayed et al16., (2000) Cotton et.a17., (1999) In addition to that, the $\mathrm{Cu}(\mathrm{II})$, and $\mathrm{Zn}$ (II) complexes are found to have magnetic moment value of 4.62 B.M.and 4.72B.M.respectively which indicates the presence of $\mathrm{Cu}$ (II) and $\mathrm{Zn}$ (II) complexes have tetrahedral structure. 3.6 THERMAL ANALYSIS (TGA AND DTG) In the present investigation, the weight losses for each complex were calculated within corresponding temperature ranges. The obtained data are listed in table (4). All complexes are thermally decomposed in three decomposition steps within the temperature range of $50-600^{\circ} \mathrm{C}$.The TGA/DTA data for the complexes are shown in Table-1,2 and 5 The thermoanalytical data are presented in table 1,2 and 5. In studying the decomposition kinetics 18-26, three methods mentioned in the literature were used in each case the least square plots were drawn. The first few points that did not fall on straight line were discarded. These types of deviations of points are reported in literature by several research workers. This is explained as due to the failure of obeying as first order kinetics always by the solids in their decomposition in the early stages fig-1 and 2.. Theoretical Consideration To provide further evidence regarding the degradation system of analyzed compounds we derived the TG curves by applying an analytical method proposed by Freeman-Carroll27-28 and Sharp-Wentworth29-30. Freeman-Carroll Method26-27 The straight line equation derived by Freeman and Carroll, which is in the form of $(\Delta \log$ $\mathrm{dw} / \mathrm{dt}) /(\Delta \log \mathrm{Wr})=\mathrm{n}-\mathrm{E}_{-} \mathrm{a} / 2.303 \mathrm{R} .(\Delta 1 / \mathrm{T}) /(\Delta \log \mathrm{Wr})$ Where, $\mathrm{dw} / \mathrm{dt}=$ rate of change of weight with time $\mathrm{Wr}=\mathrm{Wc}-\mathrm{W} \mathrm{Wc}=\mathrm{Wt}$. loss at completion of reaction

$\mathrm{W}=$ Total wt. loss upto time „t" Ea $=$ Energy of activation $n=$ Order of reaction The plot between the term $(\Delta \log d w / d T) /(\Delta \log W \mathrm{Wr}) \mathrm{Vs}(\Delta 1 / \mathrm{T}) /(\Delta \log / \mathrm{Wr})$

gives a straight line from which slope can be calculated, also we obtained energy of activation (Ea) and intercept on Y-axis as order of reaction (n). The change in entropy $(\Delta S)$, frequency factor $(Z)$, apparent entropy $\left(S^{*}\right)$ can also be calculated by further calculation. Sharp-Wentworth Method28-29 Using the 
equation derived by Sharp and Wentworth $(\Delta \log \mathrm{dc} / \mathrm{dT}) /((1-\mathrm{c}))=\log \mathrm{A} / \mathrm{B}-$ Eq/(2.303 R).1/T Where, dc/dT = Rate of change of fraction of weight with change in temperature. $\beta=$ Linear heating rate $d T / d t$ by plotting the graph between $(\Delta \log \mathrm{dc} / \mathrm{dT}) /((1-\mathrm{c})) \mathrm{Vs}=1 / \mathrm{T}$, We obtained the straight line which gives energy of activation (Ea) from its slope. The thermodynamic activation parameters of decomposition process of dehydrate complexes namely activation energy (Ea), enthalpy $(\Delta H)$, Entropy $(\Delta S)$ and Gibb"s free energy change of decomposition $\left(\Delta G^{\circ}\right)$ are evaluated graphically by employing Free man-Carroll and Sharp-Wentworth relation. The data are summarized in Table 1,2,5. The activation energies of decomposition are found to be in the range 29.70 to 204.7 KJ.Mole-1. The high value of activation energies reflect the thermal stability of complexes. The entropy of activation is found to have negative values in all the complexes which indicate that decomposition reactions process with lower rate than the normal ones31-35 Table-1Thermogravimetric data of Glimeperide-Cu complex by Sharp-Wentworth28-29 method Temp. $\left({ }^{\circ} \mathrm{C}\right)$ ${ }^{\circ} \mathrm{K}$ Temp (T) $1000 \mathrm{~T} \%$ Mass Loss Change in Wt. 'c' grams 1-c dc dt log(dc/dt) $\log (1-\mathrm{c}) \log (\mathrm{dc} / \mathrm{dt}) / 1-\mathrm{c}$ Weight \% (\%) 303033.300330 .6380 .000060 .99994 $0.00009-4.05164-0.00003-4.0518799 .362503233 .095981 .1060 .00010$ $0.999900 .00012-3.92395-0.00004-3.9243598 .894703432 .915451 .534$ $0.000140 .999860 .00017-3.77705-0.00006$-3.7775898.46690363 2.75482 2.1480 .000190 .999810 .00020 -3.69867 -0.00008 -3.69939 07.852110383 $2.610972 .6350 .000240 .999760 .00022-3.65637-0.00010-3.6572497 .365$ $1304032.481392 .9580 .000270 .999730 .00024-3.61347-0.00012-3.61444$ 97.0421504232 .364073 .2750 .000300 .999700 .00027 -3.56881-0.00013 3.5698796 .7251704432 .257343 .6290 .000330 .999670 .00030 -3.52480 $0.00014-3.5259696 .3711904632 .159834 .0170 .000360 .999640 .00033$ $3.48241-0.00016-3.4836895 .9832104832 .070394 .4320 .000400 .99960$ $0.00038-3.42467-0.00017-3.4260595 .5682305031 .988075 .0310 .00046$ $0.999540 .00042-3.38055-0.00020$-3.38209 94.9692505231 .912055 .594 $0.000510 .999490 .00050-3.30383-0.00022-3.3055194 .406270543$ 
$1.841626 .5930 .000600 .999400 .00057-3.24715-0.00026-3.2490993 .407$ $2905631.776207 .5560 .000690 .999310 .00059-3.23207-0.00030-3.23429$ $92.4443105831 .715277 .9690 .000720 .999280 .00061-3.21413-0.00031$ 3.2164592 .0313306031 .658378 .3240 .000760 .999240 .00063 -3.19810 $0.00033-3.2005291 .6763506231 .605148 .6480 .000780 .999220 .00065$ $3.18558-0.00034-3.1880891 .3523706431 .555218 .9170 .000810 .99919$ $0.00067-3.17559-0.00035-3.1781791 .0833906631 .508309 .1380 .00083$

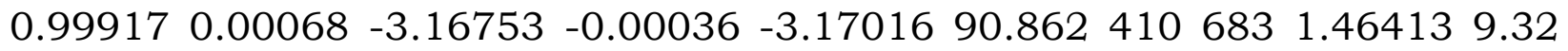
$\begin{array}{lllllllll}0.00085 & 0.99915 & 0.00069 & -3.16117 & -0.00037 & -3.16384 & 90.680 & 430 & 703\end{array}$ $1.422489 .4670 .000860 .999140 .00070-3.15540-0.00037-3.1581290 .533$ $4507231.383139 .5980 .000870 .999130 .00071-3.14976-0.00038-3.15250$ $90.4024707431 .345909 .7250 .000880 .999120 .00072-3.14431-0.00038$ $3.1470890 .2754907631 .310629 .8490 .000890 .999110 .00073-3.13884$ 0.00039 -3.1416490.151510783 1.277149.9740.000910.999090.00889 -

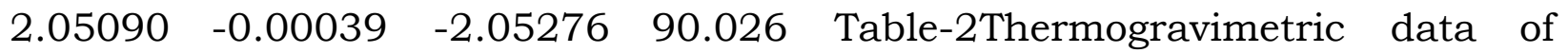
Glimeperide-Cu complex by Freeman and Carroll26-27 method Temp $\left({ }^{\circ} \mathrm{C}\right) \%$

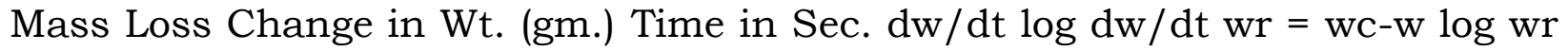
$\mathrm{T}(\mathrm{K}) 1 / \mathrm{T}(\mathrm{K}-1)(\log \mathrm{dt} / \mathrm{dt}) /(\log \mathrm{wr}(1 / \mathrm{T}) / \log \mathrm{wr} \mathrm{a}=\mathrm{wt} / \mathrm{wc} \mathrm{ga}=1-(1-\mathrm{a}) 1-\mathrm{n} / 1-\mathrm{n}$ T3 x 10-7 ga/T3 x107 1/T x 10-3 log g(a)/T3 304.0490 .000205790 $\begin{array}{llllllll}0.0004250 & -3.3717 & 0.003171 & -2.498866 & 303 & 0.003300 & 1.3493 & -0.001321\end{array}$

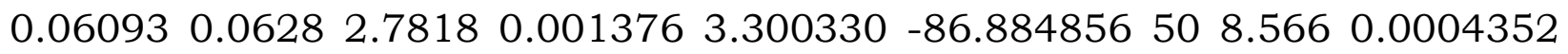
$1500.0004479-3.34880 .002941-2.5315003230 .0030961 .3229-0.001223$

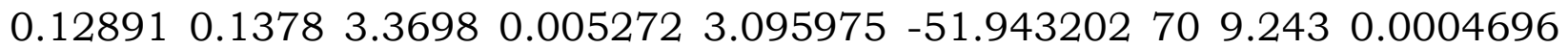
$2100.0004567-3.34030 .002907-2.5366093430 .0029151 .3169-0.001149$

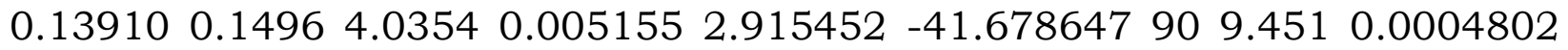
$2700.0004616-3.33570 .002896-2.5381913630 .0027551 .3142-0.001085$ $0.142230 .15324 .78320 .0045552 .754821-34.7423021109 .5580 .0004856$ $3300.0004679-3.32990 .002891-2.5390073830 .0026111 .3115-0.001028$ $0.143840 .15515 .61820 .0039702 .610966-29.3979271309 .6860 .0004921$ $3900.0004797-3.31900 .002884-2.5399854030 .002481 \quad 1.3067-0.000977$ 
$0.145770 .15736 .54510 .0035032 .481390-25.0510131509 .9260 .0005043$ $4500.0005039-3.29770 .002872 \quad-2.5418264230 .002364 \quad 1.2974-0.000930$ $\begin{array}{llllllll}0.14938 & 0.1615 & 7.5687 & 0.003188 & 2.364066 & -21.370558 & 170 & 10.413\end{array}$ $0.00052915100 .0005484-3.26090 .002847-2.5455844430 .0022571 .2810$ -0.000887 0.15671 0.1702 8.6938 0.003067 2.257336-18.10571319011.314 0.00057495700 .0006259 -3.2035 $0.002801-2.5526234630 .0021601 .2550$ -0.000846 0.170270.18639.92530.0031962.159827-15.09936121012.884 $0.00065466300 .0007092-3.14920 .002722-2.5651704830 .0020701 .2277$ $\begin{array}{llllllll}-0.000807 & 0.19389 & 0.2151 & 11.2679 & 0.003701 & 2.070393 & -12.245875 & 230\end{array}$ 14.6030 .00074206900 .0008170 -3.0878 0.002634 -2.579336 5030.001988 $1.1971-0.0007710 .219760 .247512 .72640 .0042751 .988072-9.935268250$ $16.810 .0008541750 \quad 0.0013404$-2.8728 0.002522 -2.598228 5230.001912 $1.1057-0.0007360 .252980 .290814 .30560 .0051431 .912046$-7.922182 270 27.2210 .00138318100 .0021815 -2.66120.001993 -2.700455 5430.001842 $0.9855-0.0006820 .409650 .524316 .01030 .0134151 .841621$-4.172467290 44.2950 .00225068700 .0026006 -2.58490.001126-2.9485995630.001776 $0.8767-0.0006020 .666601 .086417 .84540 .0405831 .776199-0.785237310$ 53.3980 .00271329300 .0027506 -2.5606 0.000663 -3.178407 5830.001715 $0.8056-0.0005400 .803591 .601419 .81550 .0649411 .7152660 .552733330$ 56.8050 .00288639900 .0028234 -2.54920.000490 -3.309794 6030.001658 $0.7702-0.0005010 .854871 .893321 .92560 .0738191 .6583750 .953780350$ 58.4090 .002967810500 .0028782 -2.54090.000409-3.388795 623 $\begin{array}{llllllll}0.001605 & 0.7498 & -0.000474 & 0.87900 & 2.0680 & 24.1804 & 0.075177 & 1.605136\end{array}$

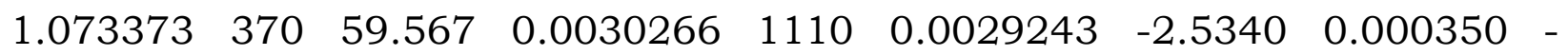
$3.4563366430 .0015550 .7331-0.0004500 .896432 .216926 .58480 .074753$ $1.5552101 .12191639060 .5310 .003075611700 .0029769-2.52620 .000301$ -3.521876 $6630.0015080 .7173-0.0004280 .910942 .360929 .14340 .073794$ $1.5082961 .14112641061 .6160 .003130712300 .0030311-2.51840 .000246$ -3.609834 $6830.0014640 .6976-0.0004060 .927272 .553531 .86120 .074314$ $1.4641291 .17488943062 .7370 .003187712900 .0030755-2.51210 .000189$ 
-3.7244437030.001422 $0.6745-0.0003820 .944144 .266034 .74290 .115930$ $1.4224751 .74153845063 .6670 .003234913500 .0031104-2.50720 .000141$ $\begin{array}{llllllll}-3.849694 & 723 & 0.001383 & 0.6513 & -0.000359 & 0.95813 & 50.0000 & 37.7933\end{array}$ $1.2675971 .3831264 .44627947064 .3990 .003272114100 .0031412-2.5029$ $0.000104-3.9822977430 .0013460 .6285-0.0003380 .969153 .360341 .0172$ $0.0793981 .3458951 .25014449065 .0420 .003304814700 .0031720-2.4987$ $0.000071-4.1457577630 .0013110 .6027-0.0003160 .978833 .710144 .4195$

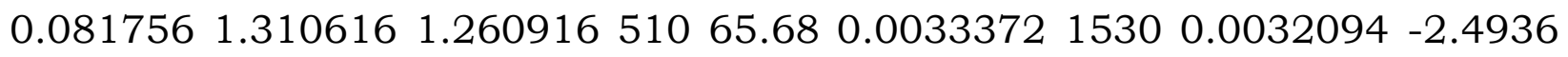
0.000039 -4.408124 7830.0012770 .5657 -0.000290 0.98843 \#REF! 48.0049 \#REF! 1.277139 \#REF! Fig 1- FC,Kinetic plot of Glimeperide complexes using TGA data. $(\mathrm{FC}=$ Freeman and Carroll) Fig- 2 Determination of activation energy by SW method TABLE-(3-ANALYTICAL DATA OF GLIMEPERIDE COMPLEXES S1. No. Molecular formula of complexes Molecular weight $(\mathrm{gm} / \mathrm{mol}) \%$ Analysis found (calculated) C H N O S Metal H2O 1 (C24H34N4O5S)2Co・2H2O 1076.16453 .18 (53.52) 6.18 (6.13) 10.38 (10.40) 17.82 (17.84) 5.84 (5.94) 5.37 (5.47) 3.54 (3.34) 2 (C24H34N4O5S)2Cu 1044.77455 .14 (55.13) 6.18 (6.31) 10.78 (10.72) 18.30 (18.37) 6.52 (6.12) 6.00 (6.08) - 3. (C24H34N4O5S)2Zn 1044.60455 .10 (55.14) 6.18 (6.31) 10.82 (10.72) 18.48 (18.38) 6.28 (6.12) 6.82 (6.06) - 4. (C24H34N4O5S)2La•2H2O 1156.14448 .88 (49.82) 2.82 (5.70) 9.66 (9.68) 16.80 (16.60) $5.62 \quad(5.53) 11.98$ (12.01) 3.28 (3.11) TABLE (4): I.R. SPECTRA (4000-400cm-1) OF THE GLM AND THEIR METAL COMPLEXES

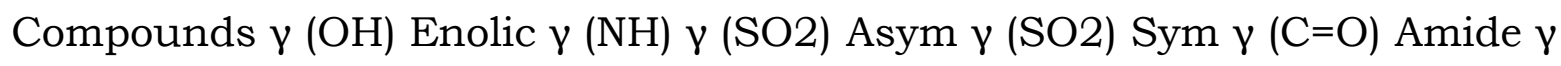
(m-O) (C24H34N4O5S)2Co•2H2O 3100-3320 Br. - 1375 sh. 1100 sh. 1460 sh. 530 m. (C24H34N4O5S)2Cu 3220-3320 br. 3100 br. 1365 sh. 1120 sh. 1481 sh. (C24H34N4O5S)2Zn 3220-3363 br. 3024 br. 1340.8 m. 1160.6 sh. 1481 sh. (C24H34N4O5S)2La-2H2O 3280-3310 - 1305 sh. 1160 w. 1480 sh. 577 m.Table (5): Thermogravimetric data of Metal complexes of GLM drugs with corresponding to heating rate of $10^{\circ} \mathrm{C} / \mathrm{min}$. Complexes Decomposition Temp. $\left({ }^{\circ} \mathrm{C}\right) \%$ Wt. loss $\mathrm{Ea}\left(\mathrm{Kj} /\right.$ mole) $\Delta \mathrm{S}^{*}\left(\mathrm{Kj} /\right.$ mole) $\Delta \mathrm{F}(\mathrm{Kj} / \mathrm{mole}) \mathrm{Z} \mathrm{S}{ }^{*}$ n F.C. W.W. [CC (C15H20N3O3S)2Cu $30-150 \quad 150-350 \quad 350-510 \quad 9.926 \quad 58.408 \quad 65.68 \quad 32.87$ 


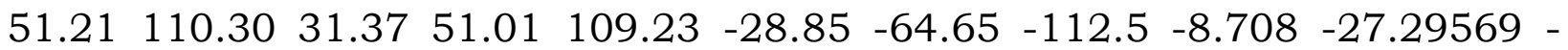

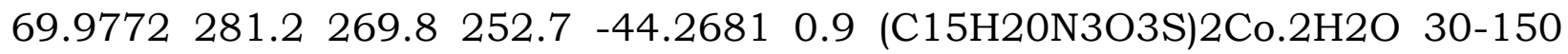

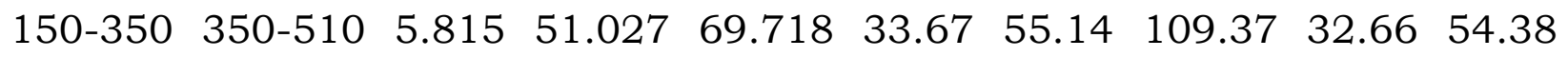

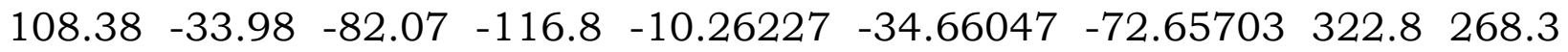
252.3 -48.5380 1.01 (C23H27O5C1N3S)2Zn 30-150 150-350 350-510 10.413 $58.40965 .04229 .7767 .76114 .228 .6866 .14113 .92-24.59-67.76-116.50$ $\begin{array}{llllllll}7.421 & -29.94992 & -72.4653 & 284.3 & 263.0 & 252.0 & -43.2123 & 0.98\end{array}$ (C24H33N4O6S)2La $30-150 \quad 150-350 \quad 350-510 \quad 2.577 \quad 61.536 \quad 81.344 \quad 52.66$ $85.94138 .2352 .1685 .13138 .14-43.48$-82.05 - 102.2 - 13.12178 -39.54421 $43.09237269 .2269 .2257 .6-44.23810 .99$

\section{Conclusion:}

Discussion The complexes of $\mathrm{Cu}, \mathrm{Zn}, \mathrm{La}$ and $\mathrm{Co}$ were synthesized with oral hypoglycemic agents i.e. glimeperide the formulae suggested for the complexes are well supported by the Jobs method of continuous variation as modified by Turner and Anderson,moreover, the formulae of the complexes further gets supports from the analytical data. The structure of the complexes are supported from variety of spectroscopic technique like I.R,Electronic spectra,TGAmethod whose results are summarized in Tables-3,4,5. All the complexes prove to be formed in 2:1 ligand metal ratio The complexes are formed after enolisation of the drugs which is indicative by the presence of only metal oxygen bonds and not the metal nitrogen. The $\mathrm{Cu}$ and $\mathrm{Zn}$ complexes shows tetrahedral structures while La and Co complexes shows octahedral structures in which the six co-ordination is fulfilled by two water molecule in which the oxygen of the water is vertically joining to the metal atom, above and below the plane of the molecule. Thus on the bases of analytical data and spectroscopic studies the following structure-1 and 2 may be assign for the $\mathrm{Cu}, \mathrm{Zn}$ and $\mathrm{La}$, Co complexes respectively. $\mathrm{M}=\mathrm{Co}$,La STRUCTURE 1 and 2 $\mathrm{M}=\mathrm{Cu}, \mathrm{Zn}$ CONCLUSION As the reported metal complexes of Glimeperide drugs are able to dissociate at stomach $\mathrm{pH}$, therefore its dosages, to be given to 
subject animals should be such that it should not be dissociate in stomach i.e. at $\mathrm{pH} 1.2$ for this complexes prepared enteric coated to make at the drug bioavailable as it is, i.e. at duodenum and small intestinal $\mathrm{pH}(5.5$ to $6.8 \mathrm{pH})$ Drug is coated with a polymer HPMC-5CPS (Hydroxy propylmethyl cellulose) which does not permit drug to dissolve in stomach (i.e. $\mathrm{pH}$ 1.2) and such polymer dissolves rapidly at deodenal $\mathrm{pH}(5-5.5)$ thus drug releases at $5.5 \mathrm{pH}$ and is available for absorption. At this $\mathrm{pH}$ complex is stable, non-dissociatable and absorbable. Therefore dosage forms for animals study is prepared as enteric coated, polymerized in this dosage forms are not soluble at $\mathrm{pH} 12$. This drug delivery system is adopted for further study36 The hypoglycemic effects Glimeperide the well known sulphonyl ureas, were inverstigated on the blood sugar levels of male albino rats by using Folin Wu method.37. Analysis of data show that thisdrugs caused a marked decrease in blood sugar level to the extent while their complexes reduced the blood sugar level to than the parent drug. This blood sugar lowering effect of sulphonyl ureas seems to be related to the stimulation of insulin secretion on the other hand, many studies have strongly indicated the presence of long term or extra pancreatic action of sulphonyl ureas38. The hypoglycemic activity of sulphonyl ureas may also be attributed to the stimulation of glycolysis and to the inhibition of glycogenesis in the liver by itself or by enhancing insulin action39. On comparing the hypoglycemic effect of these complxes with their parent drugs, it was revealed that in the three groups Glimeperide-Zn(II) treated albino rat had lowest blood sugar level being $49.72 \mathrm{mg} / 100 \mathrm{ml}$. respectively on an average. These facts clearly indicate a better hypoglycemic activity of complexes as compared to their parent drugs which is in agreement with the earlier findings of Iqbal and co-workers40. This improved hypoglycemic activity may be related to smaller particle size of metal complexes than drugs as on complexation particle size is reduced which may promote the ratio of absorption of complexes in gastrointestinal tract. Results of the present work are also in conformity with the hypoglycemic effect of copper-phenformin complex over parent drug 
phenformin as mentioned by Piccini et al.,41 These interesting observations on metal-complexes of oral sulphonylureas used as anti-diabetic agents for lowering blood sugar concentration may likely substantiate the use of these complexes after extensive clinical studies.

\section{Reference:}

Iqbal S.A.and Siddiqui A.,Orient J.Chem.,3(1);81-84(2005)

Wilma Cyril,Suresh Kumar and Shobhna D.Orient.J.Chem.27(4);16531658(2011)

Asmi Desnavi and S.A. Iqbal Orient J chem..1986 2(2),156-159 (1986)

S.A.Iqbal, S.Siddiqui, R.Qureshi and A. Desnavi Orient J. Chem.; 1(1) 32-34 (1985)

Iqbal S.A.,SibiJose and Ishaq Jaafrany,Orient.J.Chem.,28(1);613-618(2012)

Mamta Bhattacharya S.A. Iqbal and Suman Malik, Orient J. Chem 20(4); 643$646(2004)$

Priya Budhani,S.A. Iqbal and S. Malik, Chemical and Environment Research( Aligarh) (2004)

K. Nakamotto, Infrared Spectra of Inorganic and Co-ordination Compounds, John Wiley and Son"s New York Ed.(1963)

C.N.R. Rao, Chemical Applications of Infrared Spectroscopy, Academic press, New York (1963)

L.J. Belamy, The Infrared Spectra of complex Molecules, Matheum and Co-Ltd London (1964)

Cotton F. A.; Modern Co-ordination chemistry, Inter-science Pub Ed.(1960)

A.Weissberger ,Chemical Application of Spectroscopy, Inter-science publishers New York (1956) 
A.W. Coats, J.P. Redfern, Nature (London) 201,68 (1964)

H.W. Horowitz G. Metzger, Anal Chem. 35,1464 (1963)

Rosenberg,B.,Lippert B., 1999 Cisplatin Chemistry and Biochemistry of Leading Anticancer Drug,verlag chemie VCH Basel 3

Zayed M.A., Nour El-Dien, F.A.Mohamed Gehad G, El-Gamel, Nadia E.A., , J Z. Mol. Struct., 841, 41(2007)

Cotton, F.A.; Wikinson G., Murillo, C,A., Bochmann, M. Advanced inorganic chemistry, sixth ed. Wiley, New York. (1999)

P.M.Madhusudhayan, K.Krishan, K.N.Ninan Thermochim. Chem Acta 97,189 (1986);

Pandey.R.N.,Nag A.K.,Prasashti Pandey and Sanjay K.Sing,Orient.J. Chem.26(1);109-112(2010)

Rai,B.K.,and Chandan Kumar,Orient.J.Chem.26(3);989-994(2010)

Birendra Kumar,Kiran Kumar Prasad and Sanjay Kumar Shrivastav,Orient.J.Chem.26(4);1413-1418(2010)

Subi, A. AL-Jibori,Ibrahim F.,Waheed and Alif.AlSamoraie,Orient.J.Chem.28(1);257-262(2012)

Rehman,F.and Samya Majraj,Orient.J.Chem.,28(1);581-585(2012)

A. A. Alhadi S.A.Shaker W.A.Yehe,H.M.Ali and A.A. Mahmood,Orient.J. Chem.,27(4);1437-1442(2011)

A.S. AL-Janabi,and S.A.Ahmed,Orient.J.Chem.27(4);1563-1571(2011)

S.Singh,K.K.Singh and J.P. Singh,Orient.J.Chem.27(3);1233-1237(2011)

K.C. Patel, S.K. Patel and G.P. Vaidya, Orient J Chem,17, 223 (2001)

Michael PEP, Barbe J.M., Juneja H, D. and Paliwal L. J.Euro polym. J. 43,(12) 2007 
Tamami B, Yaganesh H and Koohmarch G.A Iran polym. J, 14(5) ,785-792.( 2005)

Yangesh H and Ataei S. M.Iran polym.J.,14(5),449-455(2005)

Jadho M.M., Paliwal L.J. and Bhave M.S.J App Polym Sci, 109, 508 (2008),

Gurnule W.B.,Juneja H.D. and Paliwal L.J.,Oriental J. Chem 15, 283(1999),

Mohamed G.G., Abd El-Wahwb, Z.H. J. Therm. Anal.73.347(2003)

M.R.Khan and Sahdev,Orient.J.Chem.27(2);649-653(2011)

K.Shankar and A.B.Nazeera,Orient.J.Chem.,27(2);655-660(2011)

Varshosaz,J.,Tabbakhian,M.and Zahrooni,M,:Journal of Microcapsulation, 24(3), 253-262 (2007)

Folin., O.and Wu,H:J.biol.Chem.,41,367 (1920)

Anturlikar, S.D.:Indian J.of Physiology and pharmacology,39,95-100(1995)

Iqbal,S.A.,Hussain I.Khan,M.A.Khan,N.A., and Siddiqui, N.U.,: Orient. J.Chem. 3(2), 199-202 (1987)

Qureshi,.R.and Iqbal,S.A.:Indian J.Applied and pure Biol.,2(2),65-67(1987)

Piccinni,F.Murazzi,E.,Uberti and Lu Catelli. I. :Pharmaco. (pavia) Ed. Sci., $15,521(1960)$. 
Table-1 Thermogravimetric data of Glimeperide-Cu complex by Sharp-

Wentworth ${ }^{28-29}$ method

\begin{tabular}{|c|c|c|c|c|c|c|c|c|c|c|}
\hline $\begin{array}{c}\text { Temp. } \\
\left({ }^{\circ} \mathrm{C}\right)\end{array}$ & $\begin{array}{c}{ }^{\circ} \mathbf{K} \\
\text { Temp } \\
\text { (T) }\end{array}$ & $\frac{1000}{T}$ & $\begin{array}{c}\% \\
\text { Mass } \\
\text { Loss }\end{array}$ & $\begin{array}{c}\text { Change } \\
\text { in Wt. } \\
\text { 'c' } \\
\text { grams }\end{array}$ & $1-\mathrm{c}$ & $\frac{\mathrm{dc}}{\mathrm{dt}}$ & $\log (\mathrm{dc} / \mathrm{dt})$ & $\log (1-c)$ & $\begin{array}{c}\log (d c / d t) / 1- \\
c\end{array}$ & $\begin{array}{l}\text { Weight } \\
\%(\%)\end{array}$ \\
\hline 30 & 303 & 3.30033 & 0.638 & 0.00006 & 0.99994 & 0.00009 & -4.05164 & -0.00003 & -4.05187 & 99.362 \\
\hline 50 & 323 & 3.09598 & 1.106 & 0.00010 & 0.99990 & 0.00012 & -3.92395 & \begin{tabular}{|c|}
-0.00004 \\
\end{tabular} & -3.92435 & 98.894 \\
\hline 70 & 343 & 2.91545 & 1.534 & 0.00014 & 0.99986 & 0.00017 & -3.77705 & -0.00006 & -3.77758 & 98.466 \\
\hline 90 & 363 & 2.75482 & 2.148 & 0.00019 & 0.99981 & 0.00020 & -3.69867 & -0.00008 & -3.69939 & 97.852 \\
\hline 110 & 383 & 2.61097 & 2.635 & 0.00024 & 0.99976 & 0.00022 & -3.65637 & $\begin{array}{l}-0.00010 \\
\end{array}$ & -3.65724 & 97.365 \\
\hline 130 & 403 & 2.48139 & 2.958 & 0.00027 & 0.99973 & 0.00024 & -3.61347 & -0.00012 & -3.61444 & 97.042 \\
\hline 150 & 423 & 2.36407 & 3.275 & 0.00030 & 0.99970 & 0.00027 & -3.56881 & -0.00013 & -3.56987 & 96.725 \\
\hline 170 & 443 & 2.25734 & 3.629 & 0.00033 & 0.99967 & 0.00030 & -3.52480 & -0.00014 & -3.52596 & 96.371 \\
\hline 190 & 463 & 2.15983 & 4.017 & 0.00036 & 0.99964 & 0.00033 & -3.48241 & $\begin{array}{l}-0.00016 \\
\end{array}$ & -3.48368 & 95.983 \\
\hline 210 & 483 & 2.07039 & 4.432 & 0.00040 & 0.99960 & 0.00038 & -3.42467 & $\begin{array}{l}-0.00017 \\
\end{array}$ & -3.42605 & 95.568 \\
\hline 230 & 503 & 1.98807 & 5.031 & 0.00046 & 0.99954 & 0.00042 & -3.38055 & -0.00020 & -3.38209 & 94.969 \\
\hline 250 & 523 & 1.91205 & 5.594 & 0.00051 & 0.99949 & 0.00050 & -3.30383 & -0.00022 & -3.30551 & 94.406 \\
\hline 270 & 543 & 1.84162 & 6.593 & 0.00060 & 0.99940 & 0.00057 & -3.24715 & -0.00026 & -3.24909 & 93.407 \\
\hline 290 & 563 & 1.77620 & 7.556 & 0.00069 & 0.99931 & 0.00059 & -3.23207 & -0.00030 & -3.23429 & 92.444 \\
\hline 310 & 583 & 1.71527 & 7.969 & 0.00072 & 0.99928 & 0.00061 & -3.21413 & $\begin{array}{l}-0.00031 \\
\end{array}$ & -3.21645 & 92.031 \\
\hline 330 & 603 & 1.65837 & 8.324 & 0.00076 & 0.99924 & 0.00063 & -3.19810 & -0.00033 & -3.20052 & 91.676 \\
\hline 350 & 623 & 1.60514 & 8.648 & 0.00078 & 0.99922 & 0.00065 & -3.18558 & -0.00034 & -3.18808 & 91.352 \\
\hline 370 & 643 & 1.55521 & 8.917 & 0.00081 & 0.99919 & 0.00067 & -3.17559 & -0.00035 & -3.17817 & 91.083 \\
\hline 390 & 663 & 1.50830 & 9.138 & 0.00083 & 0.99917 & 0.00068 & -3.16753 & -0.00036 & -3.17016 & 90.862 \\
\hline 410 & 683 & 1.46413 & 9.32 & 0.00085 & 0.99915 & 0.00069 & -3.16117 & -0.00037 & -3.16384 & 90.680 \\
\hline 430 & 703 & 1.42248 & 9.467 & 0.00086 & 0.99914 & 0.00070 & -3.15540 & -0.00037 & -3.15812 & 90.533 \\
\hline 450 & 723 & 1.38313 & 9.598 & 0.00087 & 0.99913 & 0.00071 & -3.14976 & $\begin{array}{l}-0.00038 \\
\end{array}$ & -3.15250 & 90.402 \\
\hline 470 & $\overline{743}$ & 1.34590 & 9.725 & 0.00088 & 0.99912 & 0.00072 & -3.14431 & -0.00038 & -3.14708 & 90.275 \\
\hline 490 & 763 & 1.31062 & 9.849 & 0.00089 & 0.99911 & 0.00073 & -3.13884 & -0.00039 & -3.14164 & 90.151 \\
\hline$\overline{510}$ & 783 & 1.27714 & 9.974 & 0.00091 & 0.99909 & 0.00889 & -2.05090 & $\begin{array}{l}-0.00039 \\
\end{array}$ & -2.05276 & 90.026 \\
\hline
\end{tabular}


Table-2 Thermogravimetric data of Glimeperide-Cu complex by Freeman and Carroll ${ }^{26-27}$ method

\begin{tabular}{|c|c|c|c|c|c|c|c|c|c|c|c|c|c|c|c|c|c|}
\hline $\begin{array}{l}\text { Te } \\
\text { m } \\
\text { p } \\
\left({ }^{\circ}\right. \\
\text { C) }\end{array}$ & $\begin{array}{c}\% \\
\text { M } \\
\text { ass } \\
\text { Lo } \\
\text { ss }\end{array}$ & $\begin{array}{c}\text { Cha } \\
\text { nge } \\
\text { in } \\
\text { Wt. } \\
\text { (gm. } \\
\text { ) }\end{array}$ & $\begin{array}{c}\mathrm{Ti} \\
\mathbf{m} \\
\mathrm{e} \\
\text { in } \\
\mathrm{Se} \\
\mathrm{c} .\end{array}$ & $\begin{array}{c}\mathrm{dw} / \\
\mathrm{dt}\end{array}$ & $\begin{array}{l}\log \\
\text { dw } \\
/ d t\end{array}$ & $\begin{array}{c}\text { wr } \\
= \\
\text { wc- } \\
\text { w }\end{array}$ & $\begin{array}{l}\text { log } \\
\text { wr }\end{array}$ & $\begin{array}{l}\mathbf{T} \\
( \\
\mathbf{K} \\
)\end{array}$ & $\begin{array}{c}1 / \mathrm{T} \\
(\mathrm{K}- \\
1)\end{array}$ & $\begin{array}{l}\text { (L } \\
\text { og } \\
\text { dt/ } \\
\text { dt) } \\
/(\mathbf{l} \\
\text { og } \\
\text { wr }\end{array}$ & $\begin{array}{l}\text { (1/T } \\
) / L o \\
\text { g wr }\end{array}$ & $\begin{array}{l}\alpha= \\
\text { wt/ } \\
\text { wc }\end{array}$ & $\begin{array}{c}\mathrm{g \alpha} \\
= \\
1- \\
(1- \\
\alpha)^{1} \\
\cdot \\
\mathrm{n} / 1 \\
-\mathrm{n}\end{array}$ & $\begin{array}{c}\mathbf{T}^{3} \\
\mathbf{X} \\
\mathbf{1 0} \\
7\end{array}$ & $\begin{array}{c}\mathbf{g \alpha} / \\
\mathbf{T 3} \\
\mathbf{x 1 0} \\
7\end{array}$ & $\begin{array}{c}\mathbf{1} / \mathbf{T} \\
\mathbf{x} \\
10^{-9}\end{array}$ & $\begin{array}{c}\mathbf{l o g} \\
\mathbf{g}(\boldsymbol{\alpha}) / / \\
\mathbf{T}^{3}\end{array}$ \\
\hline 30 & $\begin{array}{c}4.0 \\
49\end{array}$ & $\begin{array}{c}0.00 \\
0205 \\
7\end{array}$ & 90 & $\begin{array}{c}0.00 \\
0425 \\
0\end{array}$ & $\begin{array}{c}- \\
3.3 \\
71 \\
7\end{array}$ & $\begin{array}{c}0.00 \\
317 \\
1\end{array}$ & $\begin{array}{c}- \\
2.49 \\
886 \\
6\end{array}$ & $\begin{array}{l}3 \\
0 \\
3\end{array}$ & \begin{tabular}{|c|}
0.00 \\
330 \\
0
\end{tabular} & $\begin{array}{c}1.3 \\
49 \\
3\end{array}$ & $\begin{array}{c}- \\
0.00 \\
132 \\
1\end{array}$ & $\begin{array}{c}0.0 \\
609 \\
3\end{array}$ & \begin{tabular}{|c|}
0.0 \\
62 \\
8
\end{tabular} & $\begin{array}{r}2.7 \\
818\end{array}$ & $\begin{array}{c}0.00 \\
137 \\
6\end{array}$ & $\begin{array}{c}3.30 \\
033 \\
0\end{array}$ & $\begin{array}{c}- \\
86.8 \\
8485 \\
6\end{array}$ \\
\hline 50 & $\begin{array}{l}8.5 \\
66\end{array}$ & $\begin{array}{c}0.00 \\
0435 \\
2\end{array}$ & $\begin{array}{c}15 \\
0\end{array}$ & $\begin{array}{c}0.00 \\
0447 \\
9\end{array}$ & $\begin{array}{c}- \\
3.3 \\
48 \\
8\end{array}$ & $\begin{array}{c}0.00 \\
294 \\
1\end{array}$ & $\begin{array}{c}- \\
2.53 \\
150 \\
0\end{array}$ & $\begin{array}{l}3 \\
2 \\
3\end{array}$ & $\begin{array}{c}0.00 \\
309 \\
6\end{array}$ & $\begin{array}{c}1.3 \\
22 \\
9\end{array}$ & $\begin{array}{c}- \\
0.00 \\
122 \\
3\end{array}$ & $\begin{array}{c}0.1 \\
289 \\
1\end{array}$ & $\begin{array}{c}0.1 \\
37 \\
8\end{array}$ & $\begin{array}{l}3.3 \\
698\end{array}$ & $\begin{array}{c}0.00 \\
527 \\
2\end{array}$ & $\begin{array}{c}3.09 \\
597 \\
5\end{array}$ & $\begin{array}{c}- \\
51.9 \\
4320 \\
2\end{array}$ \\
\hline 70 & $\begin{array}{c}9.2 \\
43\end{array}$ & $\begin{array}{c}0.00 \\
0469 \\
6\end{array}$ & $\begin{array}{c}21 \\
0\end{array}$ & $\begin{array}{c}0.00 \\
0456 \\
7\end{array}$ & $\begin{array}{c}- \\
3.3 \\
40 \\
3\end{array}$ & $\begin{array}{c}0.00 \\
290 \\
7\end{array}$ & $\begin{array}{c}- \\
2.53 \\
660 \\
9\end{array}$ & $\begin{array}{l}3 \\
4 \\
3\end{array}$ & $\begin{array}{c}0.00 \\
291 \\
5\end{array}$ & $\begin{array}{c}1.3 \\
16 \\
9\end{array}$ & $\begin{array}{c}- \\
0.00 \\
114 \\
9\end{array}$ & $\begin{array}{c}0.1 \\
391 \\
0\end{array}$ & $\begin{array}{c}0.1 \\
49 \\
6\end{array}$ & $\begin{array}{r}4.0 \\
354\end{array}$ & $\begin{array}{c}0.00 \\
515 \\
5\end{array}$ & $\begin{array}{c}2.91 \\
545 \\
2\end{array}$ & $\begin{array}{c}- \\
41.6 \\
7864 \\
7\end{array}$ \\
\hline 90 & $\begin{array}{c}9.4 \\
51\end{array}$ & $\begin{array}{c}0.00 \\
0480 \\
2\end{array}$ & $\begin{array}{c}27 \\
0\end{array}$ & $\begin{array}{c}0.00 \\
0461 \\
6\end{array}$ & $\begin{array}{c}- \\
3.3 \\
35 \\
7\end{array}$ & $\begin{array}{c}0.00 \\
289 \\
6\end{array}$ & $\begin{array}{c}- \\
2.53 \\
819 \\
1\end{array}$ & $\begin{array}{l}3 \\
6 \\
3\end{array}$ & $\begin{array}{c}0.00 \\
275 \\
5\end{array}$ & $\begin{array}{c}1.3 \\
14 \\
2\end{array}$ & $\begin{array}{c}- \\
0.00 \\
108 \\
5\end{array}$ & $\begin{array}{c}0.1 \\
422 \\
3\end{array}$ & $\begin{array}{c}0.1 \\
53 \\
2\end{array}$ & $\begin{array}{l}4.7 \\
832\end{array}$ & $\begin{array}{c}0.00 \\
455 \\
5\end{array}$ & $\begin{array}{c}2.75 \\
482 \\
1\end{array}$ & $\begin{array}{c}- \\
34.7 \\
4230 \\
2\end{array}$ \\
\hline 11 & 9.5 & 0.00 & 33 & 0.00 & - & 0.00 & - & 3 & 0.00 & 1.3 & 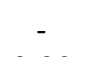 & 0.1 & 0.1 & 5.6 & 0.00 & 2.61 & - \\
\hline 0 & 58 & $\begin{array}{c}0485 \\
6\end{array}$ & 0 & $\begin{array}{c}0467 \\
9\end{array}$ & $\begin{array}{c}3.3 \\
29 \\
9\end{array}$ & $\begin{array}{c}289 \\
1\end{array}$ & $\begin{array}{c}2.53 \\
900 \\
7\end{array}$ & $\begin{array}{l}8 \\
3\end{array}$ & $\begin{array}{c}261 \\
1\end{array}$ & $\begin{array}{c}11 \\
5\end{array}$ & $\begin{array}{c}0.00 \\
102 \\
8\end{array}$ & $\begin{array}{c}438 \\
4\end{array}$ & $\begin{array}{c}55 \\
1\end{array}$ & 182 & $\begin{array}{c}397 \\
0\end{array}$ & $\begin{array}{c}096 \\
6\end{array}$ & $\begin{array}{c}29.3 \\
9792 \\
7\end{array}$ \\
\hline 13 & 9.6 & 0.00 & 39 & 0.00 & - & 0.00 & - & 4 & 0.00 & 1.3 & . & 0.1 & 0.1 & 6.5 & 0.00 & 2.48 & - \\
\hline 0 & 86 & $\begin{array}{c}0492 \\
1\end{array}$ & 0 & $\begin{array}{c}0479 \\
7\end{array}$ & $\begin{array}{c}3.3 \\
19 \\
0\end{array}$ & $\begin{array}{c}288 \\
4\end{array}$ & $\begin{array}{c}2.53 \\
998 \\
5\end{array}$ & $\begin{array}{l}0 \\
3\end{array}$ & $\begin{array}{c}248 \\
1\end{array}$ & $\begin{array}{c}06 \\
7\end{array}$ & $\begin{array}{c}0.00 \\
097 \\
7\end{array}$ & $\begin{array}{c}457 \\
7\end{array}$ & $\begin{array}{c}57 \\
3\end{array}$ & 451 & $\begin{array}{c}350 \\
3\end{array}$ & $\begin{array}{c}139 \\
0\end{array}$ & $\begin{array}{c}25.0 \\
5101 \\
3\end{array}$ \\
\hline 15 & 9.9 & 0.00 & 45 & 0.00 & - & 0.00 & - & 4 & 0.00 & 1.2 & - & 0.1 & 0.1 & 7.5 & 0.00 & 2.36 & - \\
\hline 0 & 26 & $\begin{array}{c}0504 \\
3\end{array}$ & 0 & $\begin{array}{c}0503 \\
9\end{array}$ & $\begin{array}{c}3.2 \\
97 \\
7\end{array}$ & $\begin{array}{c}287 \\
2\end{array}$ & $\begin{array}{c}2.54 \\
182 \\
6\end{array}$ & $\begin{array}{l}2 \\
3\end{array}$ & $\begin{array}{c}236 \\
4\end{array}$ & $\begin{array}{c}97 \\
4\end{array}$ & $\begin{array}{c}0.00 \\
093 \\
0\end{array}$ & $\begin{array}{c}493 \\
8\end{array}$ & $\begin{array}{c}61 \\
5\end{array}$ & 687 & $\begin{array}{c}318 \\
8\end{array}$ & $\begin{array}{c}406 \\
6\end{array}$ & $\begin{array}{c}21.3 \\
7055 \\
8\end{array}$ \\
\hline 17 & 10. & 0.00 & 51 & 0.00 & - & 0.00 & - & 4 & 0.00 & 1.2 & - & 0.1 & 0.1 & 8.6 & 0.00 & 2.25 & - \\
\hline 0 & $\begin{array}{c}41 \\
3\end{array}$ & $\begin{array}{c}0529 \\
1\end{array}$ & 0 & $\begin{array}{c}0548 \\
4\end{array}$ & $\begin{array}{c}3.2 \\
60 \\
9\end{array}$ & $\begin{array}{c}284 \\
7\end{array}$ & $\begin{array}{c}2.54 \\
558 \\
4\end{array}$ & $\begin{array}{l}4 \\
3\end{array}$ & $\begin{array}{c}225 \\
7\end{array}$ & $\begin{array}{c}81 \\
0\end{array}$ & $\begin{array}{c}0.00 \\
088 \\
7\end{array}$ & $\begin{array}{c}567 \\
1\end{array}$ & $\begin{array}{c}70 \\
2\end{array}$ & 938 & $\begin{array}{c}306 \\
7\end{array}$ & $\begin{array}{c}733 \\
6\end{array}$ & $\begin{array}{c}18.1 \\
0571 \\
3\end{array}$ \\
\hline 19 & 11. & 0.00 & 57 & 0.00 & - & 0.00 & - & 4 & 0.00 & 1.2 & 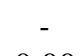 & 0.1 & 0.1 & 9.9 & 0.00 & 2.15 & - \\
\hline 0 & $\begin{array}{c}31 \\
4\end{array}$ & $\begin{array}{c}0574 \\
9\end{array}$ & 0 & $\begin{array}{c}0625 \\
9\end{array}$ & $\begin{array}{c}3.2 \\
03 \\
5\end{array}$ & $\begin{array}{c}280 \\
1\end{array}$ & $\begin{array}{c}2.55 \\
262 \\
3\end{array}$ & $\begin{array}{l}6 \\
3\end{array}$ & $\begin{array}{c}216 \\
0\end{array}$ & $\begin{array}{c}55 \\
0\end{array}$ & $\begin{array}{c}0.00 \\
084 \\
6\end{array}$ & $\begin{array}{c}702 \\
7\end{array}$ & $\begin{array}{c}86 \\
3\end{array}$ & 253 & $\begin{array}{c}319 \\
6\end{array}$ & $\begin{array}{c}982 \\
7\end{array}$ & $\begin{array}{c}15.0 \\
9936 \\
1\end{array}$ \\
\hline $\begin{array}{c}21 \\
0\end{array}$ & $\begin{array}{c}12 . \\
88 \\
4\end{array}$ & $\begin{array}{c}0.00 \\
0654 \\
6\end{array}$ & $\begin{array}{c}63 \\
0\end{array}$ & $\begin{array}{c}0.00 \\
0709 \\
2\end{array}$ & $\begin{array}{c}- \\
3.1 \\
49 \\
2\end{array}$ & $\begin{array}{c}0.00 \\
272 \\
2\end{array}$ & $\begin{array}{c}- \\
2.56 \\
517 \\
0\end{array}$ & $\begin{array}{l}4 \\
8 \\
3\end{array}$ & $\begin{array}{c}0.00 \\
207 \\
0\end{array}$ & $\begin{array}{c}1.2 \\
27 \\
7\end{array}$ & $\begin{array}{c}- \\
0.00 \\
080 \\
7\end{array}$ & $\begin{array}{c}0.1 \\
938 \\
9\end{array}$ & $\begin{array}{c}0.2 \\
15 \\
1\end{array}$ & $\begin{array}{c}11 . \\
267 \\
9\end{array}$ & $\begin{array}{c}0.00 \\
370 \\
1\end{array}$ & $\begin{array}{c}2.07 \\
039 \\
3\end{array}$ & $\begin{array}{c}- \\
12.2 \\
4587 \\
5\end{array}$ \\
\hline
\end{tabular}




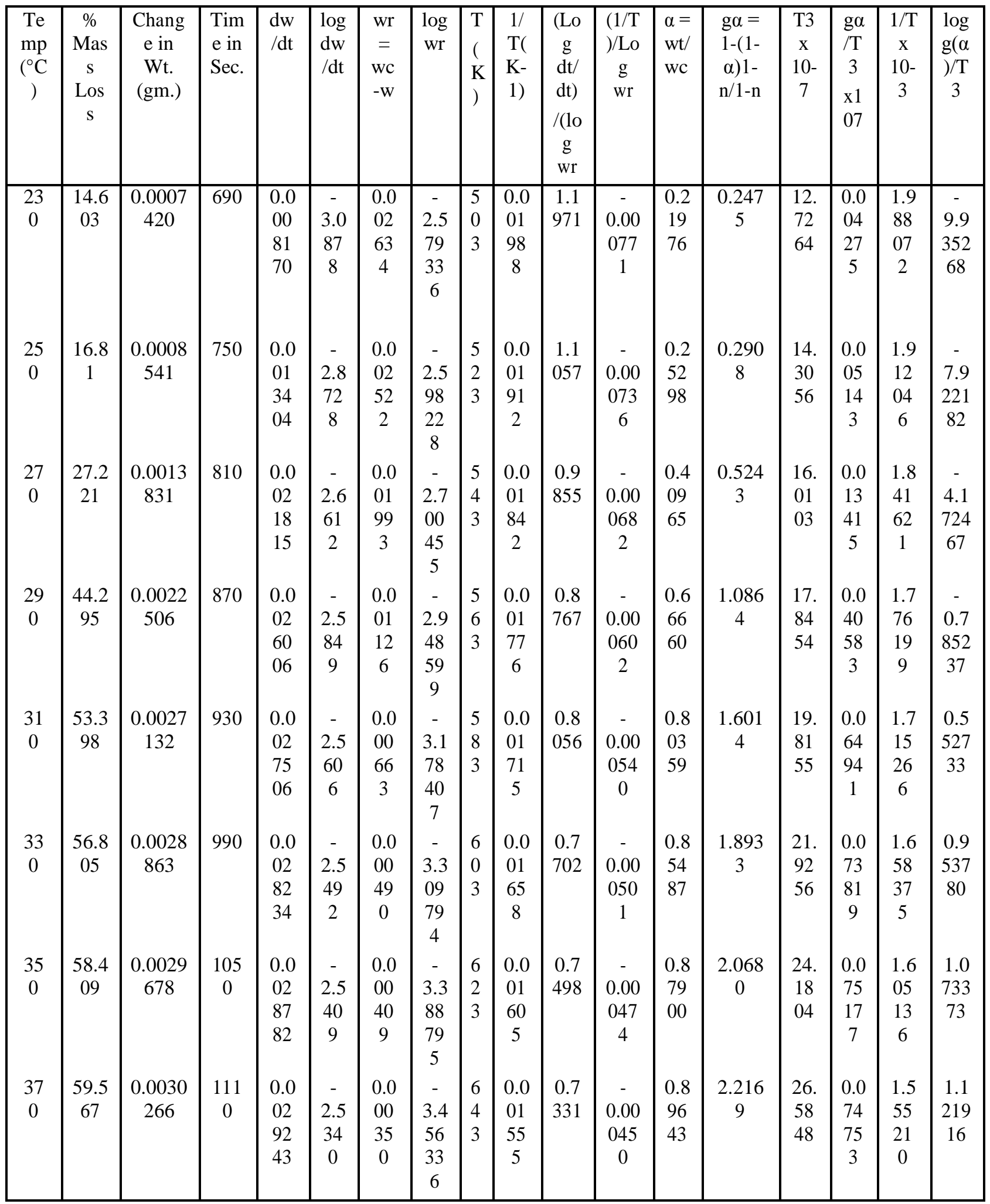




\begin{tabular}{|c|c|c|c|c|c|c|c|c|c|c|c|c|c|c|c|c|c|}
\hline $\begin{array}{c}\mathrm{Te} \\
\mathrm{mp} \\
\left({ }^{\circ} \mathrm{C}\right. \\
)\end{array}$ & $\begin{array}{c}\% \\
\text { Mas } \\
\text { s } \\
\text { Los } \\
\text { s }\end{array}$ & $\begin{array}{c}\text { Chang } \\
\text { e in } \\
\text { Wt. } \\
\text { (gm.) }\end{array}$ & $\begin{array}{l}\text { Tim } \\
\text { e in } \\
\text { Sec. }\end{array}$ & $\begin{array}{l}\mathrm{dw} \\
/ \mathrm{dt}\end{array}$ & $\begin{array}{l}\log \\
\mathrm{dw} \\
/ \mathrm{dt}\end{array}$ & $\begin{array}{c}\text { wr } \\
= \\
\text { wc } \\
-w\end{array}$ & $\begin{array}{l}\log \\
\text { wr }\end{array}$ & $\begin{array}{l}\mathrm{T} \\
( \\
\mathrm{K} \\
)\end{array}$ & $\begin{array}{l}1 / \\
\mathrm{T}( \\
\mathrm{K}- \\
1)\end{array}$ & $\begin{array}{c}\text { (Lo } \\
\mathrm{g} \\
\mathrm{dt} / \\
\mathrm{dt}) \\
/(\mathrm{lo} \\
\mathrm{g} \\
\mathrm{wr}\end{array}$ & $\begin{array}{c}(1 / \mathrm{T} \\
) / \mathrm{Lo} \\
\mathrm{g} \\
\mathrm{wr}\end{array}$ & $\begin{array}{l}\alpha= \\
w t / \\
w c\end{array}$ & $\begin{array}{c}\mathrm{g} \alpha= \\
1-(1- \\
\alpha) 1- \\
\mathrm{n} / 1-\mathrm{n}\end{array}$ & $\begin{array}{c}\mathrm{T} 3 \\
\mathrm{x} \\
10- \\
7\end{array}$ & $\begin{array}{c}\mathrm{g} \alpha \\
/ \mathrm{T} \\
3 \\
\mathrm{x} 1 \\
07\end{array}$ & $\begin{array}{c}1 / \mathrm{T} \\
\mathrm{X} \\
10- \\
3\end{array}$ & $\begin{array}{l}\log \\
\mathrm{g}(\alpha \\
) / \mathrm{T} \\
3\end{array}$ \\
\hline 390 & $\begin{array}{c}60.5 \\
31\end{array}$ & $\begin{array}{c}0.0030 \\
756\end{array}$ & $\begin{array}{c}117 \\
0\end{array}$ & $\begin{array}{l}0.0 \\
02 \\
97 \\
69\end{array}$ & $\begin{array}{c}- \\
2.5 \\
26 \\
2\end{array}$ & $\begin{array}{c}0.0 \\
00 \\
30 \\
1\end{array}$ & $\begin{array}{c}- \\
3.5 \\
21 \\
87 \\
6\end{array}$ & $\begin{array}{l}6 \\
6 \\
3 \\
\end{array}$ & $\begin{array}{c}0.0 \\
01 \\
50 \\
8\end{array}$ & $\begin{array}{c}0.7 \\
17 \\
3\end{array}$ & $\begin{array}{c}- \\
0.00 \\
042 \\
8\end{array}$ & $\begin{array}{l}0.9 \\
10 \\
94\end{array}$ & $\begin{array}{c}2.360 \\
9\end{array}$ & $\begin{array}{l}29 . \\
14 \\
34\end{array}$ & $\begin{array}{c}0.0 \\
73 \\
79 \\
4\end{array}$ & $\begin{array}{c}1.5 \\
08 \\
29 \\
6\end{array}$ & $\begin{array}{c}1.1 \\
411 \\
26\end{array}$ \\
\hline 410 & $\begin{array}{c}61.6 \\
16\end{array}$ & $\begin{array}{c}0.0031 \\
307\end{array}$ & $\begin{array}{c}123 \\
0\end{array}$ & $\begin{array}{l}0.0 \\
03 \\
03 \\
11\end{array}$ & $\begin{array}{c}- \\
2.5 \\
18 \\
4\end{array}$ & $\begin{array}{c}0.0 \\
00 \\
24 \\
6\end{array}$ & $\begin{array}{c}- \\
3.6 \\
09 \\
83 \\
4\end{array}$ & $\begin{array}{l}6 \\
8 \\
3\end{array}$ & $\begin{array}{c}0.0 \\
01 \\
46 \\
4\end{array}$ & $\begin{array}{c}0.6 \\
97 \\
6\end{array}$ & $\begin{array}{c}- \\
0.00 \\
040 \\
6\end{array}$ & $\begin{array}{l}0.9 \\
27 \\
27\end{array}$ & $\begin{array}{c}2.553 \\
5\end{array}$ & $\begin{array}{l}31 . \\
86 \\
12\end{array}$ & $\begin{array}{c}0.0 \\
74 \\
31 \\
4\end{array}$ & $\begin{array}{c}1.4 \\
64 \\
12 \\
9\end{array}$ & $\begin{array}{c}1.1 \\
748 \\
89\end{array}$ \\
\hline 430 & $\begin{array}{c}62.7 \\
37\end{array}$ & $\begin{array}{c}0.0031 \\
877\end{array}$ & $\begin{array}{c}129 \\
0\end{array}$ & $\begin{array}{l}0.0 \\
03 \\
07 \\
55\end{array}$ & $\begin{array}{c}- \\
2.5 \\
12 \\
1\end{array}$ & $\begin{array}{c}0.0 \\
00 \\
18 \\
9\end{array}$ & $\begin{array}{c}- \\
3.7 \\
24 \\
44 \\
3\end{array}$ & $\begin{array}{l}7 \\
0 \\
3\end{array}$ & $\begin{array}{c}0.0 \\
01 \\
42 \\
2\end{array}$ & $\begin{array}{c}0.6 \\
74 \\
5\end{array}$ & $\begin{array}{c}- \\
0.00 \\
038 \\
2\end{array}$ & $\begin{array}{l}0.9 \\
44 \\
14\end{array}$ & $\begin{array}{c}4.266 \\
0\end{array}$ & $\begin{array}{l}34 . \\
74 \\
29\end{array}$ & $\begin{array}{c}0.1 \\
15 \\
93 \\
0\end{array}$ & $\begin{array}{c}1.4 \\
22 \\
47 \\
5\end{array}$ & $\begin{array}{c}1.7 \\
415 \\
38\end{array}$ \\
\hline 450 & $\begin{array}{c}63.6 \\
67\end{array}$ & $\begin{array}{c}0.0032 \\
349\end{array}$ & $\begin{array}{c}135 \\
0\end{array}$ & $\begin{array}{l}0.0 \\
03 \\
11 \\
04\end{array}$ & $\begin{array}{c}- \\
2.5 \\
07 \\
2\end{array}$ & $\begin{array}{c}0.0 \\
00 \\
14 \\
1\end{array}$ & $\begin{array}{c}- \\
3.8 \\
49 \\
69 \\
4\end{array}$ & $\begin{array}{l}7 \\
2 \\
3\end{array}$ & $\begin{array}{c}0.0 \\
01 \\
38 \\
3\end{array}$ & $\begin{array}{c}0.6 \\
51 \\
3\end{array}$ & $\begin{array}{c}- \\
0.00 \\
035 \\
9\end{array}$ & $\begin{array}{l}0.9 \\
58 \\
13\end{array}$ & $\begin{array}{c}50.00 \\
00\end{array}$ & $\begin{array}{l}37 . \\
79 \\
33\end{array}$ & $\begin{array}{c}1.2 \\
67 \\
59 \\
7\end{array}$ & $\begin{array}{c}1.3 \\
83 \\
12 \\
6\end{array}$ & $\begin{array}{c}4.4 \\
462 \\
79\end{array}$ \\
\hline 470 & $\begin{array}{c}64.3 \\
99\end{array}$ & $\begin{array}{c}0.0032 \\
721\end{array}$ & $\begin{array}{c}141 \\
0\end{array}$ & $\begin{array}{l}0.0 \\
03 \\
14 \\
12\end{array}$ & $\begin{array}{c}- \\
2.5 \\
02 \\
9\end{array}$ & $\begin{array}{c}0.0 \\
00 \\
10 \\
4\end{array}$ & $\begin{array}{c}- \\
3.9 \\
82 \\
29 \\
7\end{array}$ & $\begin{array}{l}7 \\
4 \\
3\end{array}$ & $\begin{array}{c}0.0 \\
01 \\
34 \\
6\end{array}$ & $\begin{array}{c}0.6 \\
28 \\
5\end{array}$ & $\begin{array}{c}- \\
0.00 \\
033 \\
8\end{array}$ & $\begin{array}{l}0.9 \\
69 \\
15\end{array}$ & $\begin{array}{c}3.360 \\
3\end{array}$ & $\begin{array}{l}41 . \\
01 \\
72\end{array}$ & $\begin{array}{c}0.0 \\
79 \\
39 \\
8\end{array}$ & $\begin{array}{c}1.3 \\
45 \\
89 \\
5\end{array}$ & $\begin{array}{c}1.2 \\
501 \\
44\end{array}$ \\
\hline 490 & $\begin{array}{c}65.0 \\
42\end{array}$ & $\begin{array}{c}0.0033 \\
048\end{array}$ & $\begin{array}{c}147 \\
0\end{array}$ & $\begin{array}{l}0.0 \\
03 \\
17 \\
20\end{array}$ & $\begin{array}{c}- \\
2.4 \\
98 \\
7\end{array}$ & $\begin{array}{c}0.0 \\
00 \\
07 \\
1\end{array}$ & $\begin{array}{c}- \\
4.1 \\
45 \\
75 \\
7\end{array}$ & $\begin{array}{l}7 \\
6 \\
3\end{array}$ & $\begin{array}{c}0.0 \\
01 \\
31 \\
1\end{array}$ & $\begin{array}{c}0.6 \\
02 \\
7\end{array}$ & $\begin{array}{c}- \\
0.00 \\
031 \\
6\end{array}$ & $\begin{array}{l}0.9 \\
78 \\
83\end{array}$ & $\begin{array}{c}3.710 \\
1\end{array}$ & $\begin{array}{l}44 . \\
41 \\
95\end{array}$ & $\begin{array}{c}0.0 \\
81 \\
75 \\
6\end{array}$ & $\begin{array}{c}1.3 \\
10 \\
61 \\
6\end{array}$ & $\begin{array}{c}1.2 \\
609 \\
16\end{array}$ \\
\hline 510 & $\begin{array}{c}65.6 \\
8\end{array}$ & $\begin{array}{c}0.0033 \\
372\end{array}$ & $\begin{array}{c}153 \\
0\end{array}$ & $\begin{array}{l}0.0 \\
03 \\
20 \\
94\end{array}$ & $\begin{array}{c}- \\
2.4 \\
93 \\
6\end{array}$ & $\begin{array}{c}0.0 \\
00 \\
03 \\
9\end{array}$ & $\begin{array}{c}- \\
4.4 \\
08 \\
12 \\
4\end{array}$ & $\begin{array}{l}7 \\
8 \\
3\end{array}$ & $\begin{array}{c}0.0 \\
01 \\
27 \\
7\end{array}$ & $\begin{array}{c}0.5 \\
65 \\
7\end{array}$ & $\begin{array}{c}- \\
0.00 \\
029 \\
0\end{array}$ & $\begin{array}{l}0.9 \\
88 \\
43\end{array}$ & \#REF! & $\begin{array}{l}48 . \\
00 \\
49\end{array}$ & $\begin{array}{c}\text { \#R } \\
\mathrm{EF} \\
!\end{array}$ & $\begin{array}{c}1.2 \\
77 \\
13 \\
9\end{array}$ & $\begin{array}{l}\# \mathrm{R} \\
\mathrm{EF} !\end{array}$ \\
\hline
\end{tabular}

A Four Monthly Peer Reviewed Journal VISHWASHANTI MULTIPURPOSE SOCIETY (GLOBAL PEACE MULTIPURPOSE SOCIETY) 